\title{
THE BIOLOGY OF MARSUPIALS
}


BIOLOGY AND ENVIRONMENT

General Editor: Bernard Stonehouse

THE BIOLOGY OF PENGUINS

Edited by BERNARD STONEHOUSE

THE BIOLOGY OF MARSUPIALS

Edited by BERNARD STONEHOUSE

and DESMOND GILMORE

EVOLUTIONARY ECOLOGY

Edited by BERNARD STONEHOUSE

and $\mathrm{C} . \mathrm{M}$. PERRINS 


\title{
THE BIOLOGY OF MARSUPIALS
}

\author{
Edited by \\ BERNARD STONEHOUSE
}

School of Environmental Science

University of Bradford, England

and

DESMOND GILMORE

Department of Physiology

University of Glasgow, Scotland 
(C) The Contributors 1977

Softcover reprint of the hardcover 1st edition 1977 978-0-333-18795-1

All rights reserved. No part of this publication may

be reproduced or transmitted, in any form or by

any means, without permission

First published 1977 by

THE MACMILLAN PRESS LTD

London and Basingstoke

Associated companies in New York Dublin

Melbourne Johannesburg and Madras

ISBN 978-1-349-02723-1 ISBN 978-1-349-02721-7 (eBook)

DOI 10.1007/978-1-349-02721-7

This book is sold subject to the standard conditions

of the Net Book Agreement 


\section{Contributors}

ARUNDEL, J. H - Veterinary Clinical Centre, University of Melbourne, Werribee, Victoria 3030, Australia

BARBOUR, R. A. - Department of Anatomy and Histology, University of Adelaide, South Australia 5001

BARKER, I. K. - Ontario Veterinary College, Guelph, Canada

BEVERIDGE, I. - Veterinary Clinical Centre, University of Melbourne, Werribee, Victoria 3030, Australia

Bradley, A. J. - Department of Physiology, Monash University, Clayton, Victoria 3168, Australia

Braithwaite, R. W. - Department of Physiology, Monash University, Clayton, Victoria 3168, Australia

Buchmann, O. L. K. - Department of Zoology, University of Tasmania, Hobart, Tasmania

CALABY, J. H. - Division of Wildlife Research, C.S.I.R.O., Lyneham, ACT, Australia

Clemens, W. A. - Department of Paleontology, University of California, Berkeley, California 94720, USA

Crompton, A. W. - Museum of Comparative Zoology, Harvard University, Cambridge, Mass., USA

Gilmore, D. P. - Institute of Physiology, University of Glasgow, Glasgow, UK

GUILER, E. R. - Department of Zoology, University of Tasmania, Hobart, Tasmania

HAYMAN, D. L. - Department of Genetics, University of Adelaide, South Australia 5001

HEARN, J. P. - MRC Unit of Reproductive Biology, Forrest Road, Edinburgh, UK

HiIEmaE, K. - Unit of Anatomy with special reference to Dentistry, Guy's Hospital Medical School, London, UK

KeAst, A. - Department of Biology, Queen's University, Kingston, Ontario, Canada

KIRKBY, R. J. - Department of Behavioural Sciences, Lincoln Institute, Carebon, Victoria 3053, Australia

KiRSCH, J. A. W. - Peabody Museum of Natural History, Yale University, New Haven, Conn., USA

LEE, A. K. - Department of Physiology, Monash University, Clayton, Victoria 3168, Australia

McDonald, I. R. - Department of Zoology, Monash University, Clayton, Victoria 3168, Australia

MARTIN, P. G. - Department of Botany, University of Adelaide, South Australia 5001

Newsome, A. E. - Division of Wildlife Research, C.S.I.R.O., Lyneham, ACT, Australia 
PACker, W. C. - Department of Zoology, University of Western Australia, Nedlands, Western Australia 6009

PARKER, P. - Museum of Comparative Zoology, Harvard University, Cambridge, Mass., USA

REID, I. A. - Department of Physiology, School of Medicine, University of California, San Francisco 94143, USA

SAllIS, J. D. - Department of Biochemistry, University of Tasmania, Hobart, Tasmania

Setchell, B. - ARC Institute of Animal Physiology, Babraham, Cambridge, UK STODART, Eleanor - 38 James Street, Curtin, ACT, Australia

StONEHOUSE, B. - School of Environmental Science, University of Bradford, Bradford, UK

Thexton, A. J. - Royal Dental Hospital School of Dental Surgery, London, UK W EBB, S. - Department of Zoology, La Trobe University, Melbourne, Victoria, Australia

Woolley, P. - Department of Zoology, La Trobe University, Melbourne, Victoria, Australia

ZIEGLER, A. C. - Bishop Museum, Honolulu, Hawaii 96818, USA 


\section{Contents}

1 Introduction: the marsupials B. Stonehouse

SECTION 1 THE SPECIES AND THEIR CHROMOSOMES

2 The species of living marsupials: an annotated list

J. A. W. Kirsch and J. H. Calaby

3 Chromosome number - constancy and variation

D. L. Hayman

SECTION 2 ORIGINS AND EVOLUTION OF MARSUPIALS

4 Phylogeny of the marsupials

W. A. Clemens

5 Historical biogeography of the marsupials

A. Keast

6 Marsupial biogeography and plate tectonics

P. G. Martin

7 Evolution of New Guinea's marsupial fauna in response to a forested environment

A. C. Ziegler

SeCtion 3 Population, SPECIES AND behaviour Studies of MARSUPIALS

8 Diseases of marsupials

J. H. Arundel, I. K. Barker and I. Beveridge

9. Behaviour and ecology of the Tasmanian devil, Sarcophilus harrisii

O. L. K. Buchmann and E. R. Guiler

10 The success of marsupials as introduced species

D. P. Gilmore

11 Breeding and behaviour of Australian bandicoots

E. Stodart

12 Learning and problem -solving behaviour in marsupials

R. J. Kirkby

13 Corticosteroid levels and male mortality in Antechinus stuartii

A. K. Lee, A. J. Bradley and R. W. Braithwaite

14 Imbalance in the sex ratio and age structure of the Red kangaroo, Macropus rufus, in central Australia

A. E. Newsome 
SECTION 4 ANATOMY OF MARSUPIALS

15 Anatomy of marsupials

R. A. Barbour

16 An ecological comparison of marsupial and placental patterns of reproduction

P. Parker

17 The activity of the jaw and hyoid musculature in the Virginian opossum, Didelphis virginiana

A. W. Crompton, A. J. Thexton, P. Parker and K. Hiiemae

18 The penis of dasyurid marsupials

$P$. Woolley and $S$. J. Webb

SECTION 5 CELlULAR, ENDOCRINE AND METABOLIC STUDIES OF MARSUPIALS

19 Unusual plasma acid phosphatase activity in two species of Tasmanian marsupials

J. D. Sallis and E. R. Guiler

20 Pituitary function in marsupial reproduction

J. P. Hearn

21 Adrenocortical functions in marsupials

I. R. McDonald

22 A metabolic study of the Quokka, Setonix brachyurus, in varying regimes of temperature and humidity

W. C. Packer

23 Some aspects of renal physiology in the Brush-tailed possum, Trichosurus vulpecula

I. A. Reid

24 Reproduction in male marsupials

B. P. Setchell

Author Index

Subject Index 